\title{
LEGAL NATURE OF THE SHARE OF PARTICIPATION TO RECYCLING AND COMPARISON THEREOF WITH THE FOREIGN COUNTRY PRACTICES
}

\author{
Güneş YILMAZ ${ }^{1}$
}

Özgür BIYAN²

\begin{abstract}
One of the tools used to fight against the environmental pollution is the taxes. The taxes regarding the use of plastic bags, which is one of the causes of environmental pollution, is included in this scope, too. The share of participation to recycling, which is studied here and recently began to be implemented in Turkey, is discussed as plastic bag tax within the scope of this study. This study points out the nature of the share of participation to recycling in terms of tax and related financial obligation and scrutinizes it by way of comparison with the practices of foreign countries. It is concluded that the share of participation to recycling is a related financial obligation and thus some suggestions are put forward.
\end{abstract}

Keywords: Environmentallevies, Environmental taxes, Environmentally related taxes, Pollution taxes, Pigouvian taxes, The Share of Recovery.

JEL Code: F64, H23, K32, Q53.

\section{Introduction}

One of the instruments used to eliminate the adverse effects of the environmental pollution on human health is the taxes. Some efforts are made through the implementation of tax or related financial obligations, in an attempt to internalise the negative externalities generated by some products causing environmental pollution both during the production and consumption stage. The producers or consumers who cause any environmental pollution are liable to bear such financial obligations, based on the principle "Those who pollute shall pay".

Yet another tax applied on the shopping bags, packaging, plastic waste, etc. in use for a long time in the countries worldwide is the plastic bag taxes. Eventually, owing to the regulations made in 2019, Turkey began to implement financial obligations on plastic bags. The liability called "Share of Participation to Recycling" entered into force to be imposed not only on plastic bags, but also on mineral and vegetable oils, batteries, some electrical and electronic devices, drug packages and bottles as well as a variety of packaging materials.

The practice that began under the responsibility of the Ministry of Environment and Urbanization is implemented with the involvement of the Ministry of Treasury and Finance in the collection. Although the results of the practice, which was initiated with a view to maintain efficiency and contributing

\footnotetext{
1 Assoc. Prof. Dr., Alanya Alaaddin Keykubat University, Faculty of Management, Department of International Trade, gunes.yilmaz@alanya.edu.tr

2 Assoc. Prof. Dr., Bandırma Onyedi Eylül University, Faculty of Economics and Administrative Sciences, Department of Public Finance, obiyan@bandirma.edu.tr
} 
to recycling in the fight against environmental pollution, will be achieved over time, it is also noted that it has some hesitations about its legality and quality. In particular, we are faced with the fact that the legal nature of the payment received as "contribution" is to be analysed along with the fact that whether it is based upon a principle of legality due its content as a financial obligation.

Our study sets out the findings on the position of the mentioned share of participation to recycling, within the classification of other taxes and related financial obligations and suggests recommendations for potential issues, by way of comparison with that used in foreign countries, also considering the regulations of international organizations.

\section{The Role And Significance Of Taxational Tools In The Fight Against Environmental Pollution}

Taxational tools as financial instruments have long been used in the fight against environmental problems. However, the uncertainty about the property rights during the use of these tools as well as the failure in pricing the environmental goods and services and how these costs are to be imposed on the society, is one of the major considerations. In general, a significant consensus was reached on the fact that the individuals or organizations that damage the environment and cause negative externalities have to bear the costs. Thus, it is aimed to internalise the externalities caused (Toprak, 2006: 154).

British Economist A. C. Pigou (1877-1959) was the first person to use the term "pollution tax" in relation to the taxation of environmental pollution. In his work entitled "The Economics of Welfare", Pigou proposed externality tax against the air pollution caused by the wellknown fog in London at the time. So, upon this proposal, the environmental taxes entered the literature as Pigou tax or Pigouvian taxes (Özdemir, 2009: 19). As Pigou thinks, a certain amount of subsidy should be granted to the industries where the marginal net social product is greater than the private product; where as a certain amount of taxational liability is to be imposed in the industries where the marginal net social product is greater than the private product, in order to maintain an optimal outcome level in the industries operating in imperfect competitive conditions. In this way, the government will be able to change the outcome in a way to equalise both marginal value and enhance the economic welfare at an optimal output level. Here, Pigou advocates the idea that some sort of tax be imposed to suit the consumption or use of the unit or goods leading to a negative externality, in an effort to maintain an optimal output level, in the presence of the costs caused by negative externalities (Kargı and Yüksel, 2010: 185,194).

In addition to the positive aspects of Pigouvian taxes as mentioned above, it also involves some difficulties in practice. In the event that no tax can be levied directly on pollution due to such difficulties, the second best taxes are the indirect environmental taxes. While these taxes are similar to the Pigouvian taxes, they are levied on the production inputs and consumer goods that cause environmental pollution. We cannot talk about a direct relationship between tax paid and the negative externalities. Therefore, the effect of these taxes on the behaviors hazardous to the environmental cannot be fully predicted (Gündüz and Agun, 2013: 60).

It is seen that there is not a complete consensus in the literature, on the application of nontaxational financial obligations or charges/fees, which one of them is effective and the definitions thereof, in addition to the environmental taxes and taxes with environmental impacts. Right at 
this point, the subject of this study comprises our assessments about whether the said liability recently adopted in our country has been positioned accurately and as it should be, as well as our suggestions on the subject matter, also considering the taxes with environmental impacts and other liabilities that are currently in dispute in international practices. In this context, it can be thought that the most common and affordable measure to cut down on the use of plastic shopping bags as one of the factors causing environmental pollution and to change consumer behaviours is therefore "to levy a tax as environmental taxes". Once it is determined for what reasons a tax has been levied, it should be remembered that there is a contradiction between the desired objectives to be attained.

According to the OECD, environmental taxes "introduce a pricing mark that help the polluters to consider the costs of environmental pollution when taking production and consumption decisions". On the other hand, according to the OECD, such a tax will be satisfactory if the polluter "bears the cost of the damage it causes or the cost of waste treatment." That is, these financial measures should be based on the equivalent principle. For this reason, "Environmental taxes should be equivalent to external cost imposed on the environment; similarly, the user charge to be paid for a service has be equivalent to the costs assumed by the public sector to offer such service". In other words, due to the allocation of the costs to the polluter, as is seen above, such financial measures (based on the Pigouvian tradition) should be included in the subject of financial obligations, such as "charges or fees" rather than in the "taxes" (Livia Salvini, 2013/2014: 83-84).

\section{Determining The Legal Nature Of The Share Of Participation To Recycling}

\subsection{Right to Live in a Healthy and Balanced Environment}

Chapter VIII of the Constitution is entitled "health, environment and housing". The article 56 right below the relevant title is entitled "Healthcare services and the protection of environment" which suggests, "Everyone has the right to live in a healthy and balanced environment. It is the duty of the Government and the citizens to improve the environment protect the environmental wellbeing and prevent environmental pollution. The Government manages all healthcare institutions centrally so that they deliver uniform healthcare services, in an attempt to ensure that everyone maintains a life in a physical and mental wellbeing; to achieve cooperation by boosting the saving and efficiency in human and material force. The Government fulfils this duty by utilizing and supervising the healthcare and social institutions in the public and private sectors."

Also, the constitutions of different countries include some provisions similar to this article imposing tasks on both the government and the citizens about the protection of environment and prevention of environmental pollution. On the other hand, the principle \#16 of the regulations known as "The Rio Declaration on Environment and Development", adopted and published by UNESCO in 1992, suggests "National authorities should endeavour to promote the internalization of environmental costs and the use of economic instruments, taking into account the approach that the polluter should, in principle, bear the cost of pollution, with due regard to the public interest and without distorting international trade and investment" (http://www.unesco.org/ education/pdf/RIO_E.PDF). 
Since it is included in the national and international society and in the Constitutions, such provision requires the governments to take economic measures and the citizens to bear such measures, in an effort to protect the environment, prevent the environmental pollution and thus to enable the polluters to internalise these measures. In this respect, it is a constitutional obligation in most countries to take measures against the most important factors that can be considered "pollutants".

\subsection{Share of Participation to Recycling: Tax, Duty, Fee or Related Financial Obligation?}

\subsubsection{Legal Regulations Regarding the Share of Participation to Recycling}

Thanks to the amendment made on the Environmental Law No \#2872, with the Law Related To Making Amendments on the Environmental Law No. 7153 and on Some Laws, (art. \#3/h) is revised as follows: "imposing some compulsory standards to be complied with for the protection of environmental, prevention and elimination of environmental pollution as well as taxes, fees, contributions, promotion of renewable energy sources and clean technologies, share of participation to recycling, reducing the use of plastic bags and plastic packaging, collection of deposit, emission fee, pollution fee and collection of security towards the prevention of pollution and the use of economic instruments and incentives with the mechanisms based on carbon trade". In fact, a practice parallel with the regulations that had several variations in the international was put into practice to be effective from early 2019.

Pursuant to the regulations, share of participation to recycling is imposed on plastic shopping bags, tyres (passenger car, bus, truck, vans, loaders and excavator tyres and others, heavy/construction equipment tires), solid tires, accumulators, zinc carbon batteries, alkali cylindrical batteries, alkaline button batteries, lithium button cells, lithium cylindrical rechargeable and primary cell types (excluding vehicle batteries), automotive batteries (except those containing lead), vehicle batteries containing lithium, other rechargeable batteries, mineral oil, vegetable oils, electrical and electronic device: (except for TV/monitor), electrical and electronic device: information, telecommunication equipment (except for TV and monitors), electrical and electronic device: lighting equipment, electrical and electronic device: small household appliances and others, electrical and electronic device: White Goods (except for refrigerators/coolers/air conditioners), electrical and electronic device: Refrigerators/coolers/air conditioners and pharmaceuticals.

\subsubsection{Is Share of Participation to Recycling a Tax?}

According to the generally accepted definition of the tax, it is the compulsory, unrequited, monetary and final payments collected from the persons in proportion to their financial powers, to meet the public expenses. The fact that tax is unrequited separates it from public revenues with bold lines. In this context, a financial obligation can be considered a tax only if it is not allocated to an unrequited, namely a specific public expense.

The Environment Law stipulates that share of participation to recycling shall be recorded as revenue to the central budget (art.18). Failure to record it as a revenue is in fact an indication that it is an obligation in the form of a tax. 


\subsubsection{Is Share of Participation to Recycling a "Duty or Fee"?}

The compulsory payments made for public services used are called "duty" while the compulsory payments made to obtain a permit or licence to carry out a certain business are called "fee". Both duty and fee are the financial obligations corresponding with the theory of mutual and direct exploitation. On the other hand, with respect to the share of participation to recycling, neither public service is utilized nor any permit or licence is obtained. Therefore, it does not seem possible to consider it a duty or fee (Yılmaz and Biyan, 2016: 353).

\subsubsection{Is Share of Participation to Recycling "Related Financial Obligation"?}

Since the practice of share of participation to recycling does not have the characteristics of duty or fee in terms of legal definition and content, can it be considered within the concept of related financial obligation as defined on the constitutional basis? As a matter of fact, the each financial obligation might be identical to tax, duty and fee in some aspects. For this reason, the term "related" in the Constitution \#73 should not be construed as "limiting" or "restrictive". On the other hand, not every financial obligation, which is not a tax, duty or a fee, but a related thereto, is necessarily regarded as a related financial obligation. In this respect, it is important to determine the common characteristics required to accept an obligation as a related financial obligation. It will be a good practice to refer to the judgement of the Constitutional Court ${ }^{3}$. In one of its decisions, the Court delivered a judgement as follows: "Related financial obligation is the money received from the persons for the public services offered or collected by virtue of the power of the public without the presence of any service. While a related financial obligation sometimes reflects some of the characteristics of tax, duty and fee, it can sometimes bear such characteristics collectively. What separates a financial obligation from a tax, duty and fee is that it is not included in the general budget ${ }^{4}$. In this context, it can be seen that the basic criteria required and determined by the Constitutional Court when accepting an obligation as a "related financial obligation" is that "it can be imposed by the force of public, whenever necessary" (YIlmaz and Biyan, 2016: 361). Considering these assessments and remarks, it will be appropriate to acknowledge an obligation to be levied as a share of participation to recycling, as a "related financial obligation".

\section{Plastic Bag Tax in the World}

\subsection{Development of Practice in General}

With the increase in plastic consumption since the 1950s, current studies show that is expected to consume over 600 million tons of plastic bag a year by 2038 (David Powell, 2018: 4). In order to reduce the negative impact of plastic waste on the environment, the countries try different ways to ban or prohibit the use thereof. However, the examples in practice show that the taxation policy yields more successful results than the prohibition policy does.

\footnotetext{
3 For further information and remarks on Related Financial Obligations, refer to Gunes Yilmaz and Ozgur Biyan (2016). "An Uncertainty in Tax Law: The Concept of "Related Financial Obligation" and a Review of the Authorities Granted to the Council of Ministers in Terms of this Concept, Marmara University Journal of Economics and Administrative Sciences • Volume: 38 •Issue: 2 • December 2016, ISSN: 2149-1844, ss/pp. 349-374.

4 Decision of the Constitutional Court, E.S: 2011/16, K.S: 2012/129, K.G: 27.09.2012, Official Gazette of the Republic of Turkey dated 22.11.2013, no.28829.
} 
Denmark is the first country in the world to adopt the method of prohibition or taxation regarding the plastic bags in 1933, after which the use of plastic bags decreased remarkably by $60 \%$. However, the best results of this tax application are seen in Ireland which adopted the implementation in 2002 (Douglas Lober, 2018).

In this context, European Union Member States have already implemented several types of policy instruments to reduce the consumption of plastic bags, including policy instruments applied alone or combined. Economic instruments are the most common measures. As an example, charging for the plastic bags via taxation at the supermarkets and hypermarkets in France, Germany and Slovakia have also reduced the consumption of plastics bags (Bio Intelligence Service, 2011). Other countries/regions including Austria, France, Netherlands, and Poland have recently started to implement the Directive 2015/720, by banning the free plastic bags or through taxation. (Graca Martinho, Natacha Balaia, Ana Pires, The Portuguese plastic carrier bag tax: The effects on consumers' behavior, Waste Management 61 (2017) 3 -12, March 2017: 4).

\subsection{Overview of Country Practices}

\subsubsection{United States of America}

The federal government in the U.S. has a very limited involvement in the solid waste management locally. The federal government does not have any duties other than providing technical support, ensuring the establishment of landfill where solid waste is to be collected and helping to organize the waste facilities. The states, on the other hand, are vested with rather broad authorities. It is the primary responsibility of the local governments to plan and establish the Solid Waste Management (SWM), carry out the operations, determine and implement the policies for recycling, set out the regulations of commercial and organizational recycling and install the containers where the waste is to be collected, as part of the responsibility in SWM (Wagner, 2017: 3).

The laws regulating the responsibility within the scope of 33 states in terms of SMW were adopted and put into force since 2006-2007. The responsibilities and obligations of the producers are specified and the financial obligations of local governments, which need to be born independently of their costs, are also determined (Wagner, 2017: 3).

For example, $\$ 0.05$ was charged for paper bags and the use of plastic bags was totally prohibited in Los Angeles. Due to such fee, the use of paper bags decreased by $16 \%$. On the other hand, an increase was observed in the use of reusable bags. For example, $47 \%$ of the consumers went on shopping with their personal bags and did not ask for any bag. Likewise in Santa Barbara, California, \$0.10 was charged for each paper bag and the use of plastic bags was completely prohibited. The consumption of plastic bags decreased by $89,3 \%$ (Wagner, 2017: 7).

While \$1 was charged per plastic bag in Brownsville, Texas; \$0.10 was charged in Glendale, California; \$0.05 in Minneapolis, Minnesota; Montgomery and Portland, Maine (Wagner, 2017: 9). 


\subsubsection{Ireland}

$€ 0.15$ tax was levied per bag during the sale of plastic bags in Ireland as the first country to implement the plastic bag tax in 2002. This tax was intended to control the behavior of consumers during the use of plastic bags. Upon the introduction of tax, the rate of use of plastic bags decreased significantly by as much as $90 \%$ and annual consumption per person decreased from 328 down to 21 , but followed by the occurrence of a situation called "rebound effect", which caused the usage to rise again and eventually the usage rate per person increased from 21 up to 31. The amount of tax imposed per bag was increased by $€ 0.22$ so that the usage should not increase further (Wagner, 2017: 7). Thanks to the tax levied, total bag consumption per person decreased from 328 down to 14 in 2012. Moreover, the share of bag consumption in environmental pollution decreased from $5 \%$ to 0,21\% (Kılıçer, 2018: 59).

\subsubsection{Portugal}

"Green Tax Reform" was launched in Portugal with a legislative regulation enacted in 2014. According to the regulation that started to be implemented as of $01.02 .2015, € 0.10$ tax (VAT inc.) was levied per plastic bag. This practice resulted in different reactions of the related parties. For example, bag manufacturers incurred losses while laying off some of their workers, and tried to shift their operations to garbage bag production or similar replacement products. In the distribution sector, the compliance was more rapid. Any possible disturbances were evaded by distributing different products instead of plastic bags. On the part of the consumers, it was observed that they accommodated themselves rather quickly and easily. They appeared to have shifted towards the situations where they can avoid tax, also with the support of the Consumer Associations (Martinho, Balaia, Pires, 2017: 4).

Owing to the plastic bag tax implemented in Portugal, the number of bags consumed per person in each shopping reduced from 2.25 to 0.59 . The use of multi-use (reusable) bags increased. However, one of the interesting points observed was the increase in the use of garbage bags although the use of plastic bags decreased. An increase by $12 \%$ was observed in the sales of garbage bags (Wagner, 2017: 7). The plastic bag tax was levied as $€ 0.02$ per bag, which was collected immediately with the sale of the bag (Wagner, 2017: 8).

\subsubsection{South Africa}

The plastic bag tax which was launched as of May 9, 2003 following the talks held in May 2002 between the government and the industry and employee representatives within the relevant sector, was started as 0,46 cent per bag (Dikgang, Leiman, Visser, 2012: 59) and the consumption decreased by $76 \%$ in the first three months. Then, this figure was reduced with the pressure from the manufacturers (Dikgang, Leiman, Visser, 2012: 3340). The plastic bag tax, which was shown on the sales invoices separately, was reduced as low as 0.17 cents per bag due to pressure from the manufacturers. This decrease caused a positive reaction on the consumers' side and the bags consumption began rise rapidly (Kılıçer, 2018: 60). 


\subsubsection{Denmark}

In Denmark, which started to impose financial obligations on the bags back in 1978, as the first country to implement these levies, 20 DKK tax was charged for one kilogram of plastic bags. Freezing bags, carrying bags and zip-lock bags are exempt from the tax collected based on the principle "Those who pollute shall pay". The tax was applied either at the stage of production or during the wholesaling stage. The end users did not feel and perceive the tax directly as it was included in the price subsequently (Kılıçer, 2018: 60).

\section{Conclusion}

This study is intended to review, discuss and evaluate the legal effect and nature, appropriateness and suitability to the intended purpose of the share of participation to recycling, as an instrument which was introduced in early 2019 in our country and launched in an effort to protect the environment and internalise the environmental hazards, considering the debates and assessments in the international society as well as the practices of the individual countries.

While doing so, also the practices in our country will be reviewed, discussed and some suggestions will be proposed in the context of general theoretical concept of public finance and tax code, and based on the practical and theoretical discussions of international organisations as well as the practices of selected countries.

\section{References}

Anayasa Mahkemesi Kararı, E.S: 2011/16, K.S: 2012/129, K.G: 27.09.2012, 22.11.2013 tarih, 28829 sayılı T.C. Resmi Gazete.

Attzs, M., Maharaj, M. \& Boodhan, G. (2014). Survey and Assessment of Environmental Taxes in the Caribbean, Inter-American Development Bank, https://www.researchgate.net /.../222488011_European_Taxes-in-the-Caribbean\%20(3).pdf.

Barde, J. \& Braathen, N.A. (2005). "Environmentally Related Levies (Chapter 5)", Theory and Practice of Excise Taxation: Smoking, Drinking, Gambling, Polluting, and Driving, (Ed.) Cnossen, $\mathrm{S}$.

Bernstein, J. D. (1993). Alternative Approaches to Pollution Control and Waste Management, Regulatory and Economic Instruments, Urban Management Programme, Washington D.C., World Bank.

Boglea, V.A. \& Lacob, M.I. (2010). "New Financial Mechanism for Sustainable DevelopmentEnvironmental Taxes", Research Journal of Agriculture Science, 42 (3), pp. 438-441.

Bruvoll, A. (2009). On the Measurement of Environmental Taxes, Discussion Papers No. 599, Statistics Norway, Research Department, https://www.ssb.no/a/publikasjoner/pdf/DP /dp599.pdf.

Cadman, J., Evans S. \& Holland, M. (2005). Do A Little \& Change A Lot, Environment Group Research Report, Proposed Plastic Bag Levy - Extended Impact Assessment, Volume 1: Main Report, 2005, Scottish Executive, Environment Group Research Report 2005/06, https://www2.gov.scot/resource/doc/57346/0016899.pdf, (20.02.2019). 
Convery, F., Simon M. \& Susana F. (2007). "TheMost Popular Tax in Europe? Lessons From The Irish Plastic Bags Levy", Environ Resource Econ, 38, pp. 1-11.

Dikgang, J.,Leiman, A. \& Visser, M. (2012). "Analysis of The Plastic-Bag Levy in South Africa", Resources, Conservation and Recycling, 66, pp. 59-65.

Dikgang, J., Leiman, A. \& Visser, M. (2012). "Elasticity of Demand, Priceand Time: Lessons From South Africa's Plastic-Bag Levy", Applied Economics, 44, pp. 3339-3342.

Study on Environmental Taxes and Charges in the EU. (2001). Study on the Economic and Environmental Implications of the use of Environmental Taxes and Charges in the European Union and its Member States: Final Report, C1653/PtB/MM, http://ec.europa.eu/ environment/enveco/taxation/pdf/ch1t4_overview.pdf.

Sustainable Prosperity. (2015). Environmental Taxes in Canada, University of Ottow, https:// institute.smartprosperity.ca/sites/default/files/publications/files/SP_IS-Enviro-Tax-InCanada_FINAL.pdf.

European Environment Agency. (1996). Environmental Taxes - Implementation and Environmental Effectiveness.

European Commission. (1997). Environmental taxes and charges: The Commission presents guidelines for their efficient use in the single market, Document $\operatorname{COM}(97)$ 9, IP/97/70, https://europa.eu/rapid/press-release_IP-97-70_en.pdf.

EU. (2018). A European Strategy for Plastics in a Circular Economy, https://eur-lex.europa. eu/resource.html?uri=cellar:2df5d1d2-fac7-11e7-b8f5-01aa75ed71a1.0001. 02/ DOC_1\&format=PDF, (18.02.2019).

Eurostat. (2013). Environmeral Taxes - A statistic guide, Publications Office of the European Union, https://ec.europa.eu/eurostat/documents/3859598/5936129/KS-GQ-13-005-EN.PDF.

Eurostat. (2017). Environmental Tax Statistics, https://ec.europa.eu/eurostat/statistics-explained/ index.php/Environmental_tax_statistics.

Groosman, Britt. (1999). Pollution Tax, Center for Envronmental Economics and Management Faculty of Economics and Applied Economics, University of Ghent, https://reference. findlaw.com/lawandeconomics/2500-pollution-tax.pdf.

Gündüz, İ. O. \& Agun, B. H. (2013). “Çevre Vergilerinin Yerel Yönetim Düzeyinde Uygulanması: Avrupa Birliği ve Türkiye Uygulaması”, Maliye Finans Yazıları, 27 (99).

Han, J. \& Stanko, D. (2018). 2018 Update on IOPS Work on Fees and Charges, International Organisation of Pension Supervisors (IOPS), http://www.iopsweb.org/WP-32-2018-Updateon-IOPS-work-on-fees-and-charges.pdf.

Helbling, T. (2010). What Are Externalities? (What happens when prices do not fully capture costs), https://www.imf.org/external/pubs/ft/fandd/2010/12/pdf/basics.pdf, pp. 48.

Jacobsen, H. K., Pedersen, K. B. \& Wier M. (2003). Distribution all implications of Evironmental Taxation in Denmark, MPRA, Paper No. 65673, http://mpra.ub.uni-muenchen.de/65673/, (20.02.2019). 
Kargi, V. \& Yüksel, C. (2010). “Çevresel Dışsallıklarda Kamu Ekonomisi Çözümleri”, Maliye Dergisi, 159, Temmuz-Aralık.

Kılıçer, E. (2018). "Plastik Poşet Vergisi ve Örnek Ülke Uygulamaları”, Vergi Sorunları, 357, Haziran, pp. 55-64.

Lober, D. (2018). Plastic Bags Usage + Bans Around The World, https://www.reusethisbag.com/ articles/plastic-bag-bans-worldwide/.

Markandya, A. (1993). "Environmental Taxation: A Review of OECD Country Experiences and Prospects for Economies in Transition", Development Discussion Paper No. 471, Harvard Institute for International Development, Harvard University.

Martinhoa, G., Balaia, N. \& Pires, A. (2017). The Portuguese Plastic Carrier BagTax: The Effects On Consumers Behaviour, Waste Management, 61, http://dx.doi.org/10.1016/ j.wasman.2017.01.023.

Miller, S. \& Vela, M. (2013). Are Environmentally Related Taxes Effective?, Inter-American Development Bank, https://www.cbd.int/financial/mainstream/idb-tax.pdf.

Muralidhan, S. \& Sheenan, K. (2018). "Differences in Response by GenderTo Messaging About England's Plastic-Bag Levy", Journal of Advertising Research.

Naess, E. M. \& Smith, T. (2009). Environmentally related taxes in Norway, Doc.2009/5, https:// www.cbd.int/financial/fiscalenviron/norway-envtaxes.pdf.

OECD. (2016). OECD Policy Instruments for the Environment, http://www.oecd.org/ environment/ toolsevaluation/PINE_Metadata_Definitions_2016.pdf.

OECD. (2017). Environmental Fiscal Reform, Progress, Prospects and Pitfalls, https://www.oecd. org/tax/tax-policy/environmental-fiscal-reform-G7-environment-ministerial-meetingjune-2017.pdf.

Pawell, D. (2018). The Price is Right... Or is it? - The Case for Taxing Plastic, https:// rethinkplasticalliance.eu/wp-content/uploads/2018/07/PlasticsTax_FINAL.pdf.

Pitrone, F. (2015). Would Environmental Taxes by Any Other Name SmellSweet?, WU International Taxation Research Paper Series, 2015 (3), pp. 1-19.

Rogulski, M. (2015). “Environmental fees. Polish case study”, Environment Protection Engineering, 41 (2), pp. 81-97.

Salvini, L. (2014), Environment Taxation: A Legal Perspective, https://eprints.luiss.it/ 1291/1/20140217-pitrone.pdf, pp. 55.

Schlegelmilch, K. \& Joas, A. (2015). "Fiscal Considerations in the Design of Green Tax Reforms Evaluating their Revenue Potentials", Green Growth Knowledge Platform (GGKP), The Annual Conference: Fiscal Policies and the Green Economy Transition: Generating Knowledge, University of Venice, Italy.

Simonis, U. E. (1992). "Poverty, environment and development", Intereconomics: Review of European economic policy, 27, (2), pp. 75-85. 
Soares, C. A. D. (2011). "The Design Features of Environmental Taxes", (PhD Thesis), London School of Economics.

Speck, S., McNicholas, J. \& Markovic, M. (2001). Environmental Taxes in an Enlarged Europe, The Regıonal Environmental Center, http://pdc.ceu.hu/archive/00002423/01/SI_taxes.pdf.

The Rio Declaration on Environment and Development. (1992), http://www.unesco.org/education/ pdf/RIO_E.PDF.

Office of Policy, Economics, and Innovation Office of the Administrator. (2001). The US Experience with Economic Incentives for Protecting the Environment, U.S. Environmental Protection Agency, Washington, DC., https://www.epa.gov/sites/production/files/2017-08/documents/ ee-0216b-13.pdf.

Toprak, D. (2006). "Sürdürülebilir Kalkınma Çerçevesinde Çevre Politikaları ve Mali Araçlar", Süleyman Demirel Üniversitesi Sosyal Bilimler Enstitüsü Dergisi, 2 (4).

UNSTATS. (2012). A System of Environmental-Economic Accounting, White Cover Publication, European Commission, Food and Agriculture Orginzation, IMF, WB, UN OECD, https:// unstats.un.org/unsd/envaccounting/White_cover.pdf.

Wagner, T. P. (2017). Reducing Single-Use Plastic Shopping Bags In The USA, Waste Management, 70, http://dx.doi.org/10.1016/j.wasman.2017.09.003, pp. 3-12.

Withana, S., Brink, P. \& The Others. (2014). Environmental Tax Reform in Europe: Opportunities for the future, A report by the Institute for European Environmental Policy (IEEP) for the Netherlands Ministry of Infrastructure and the Environment, https://ieep.eu/uploads/articles/attachments/84aa183b-9f81-4b00-a4d6e93a14464252 /ETR_in_Europe_-_Final_report_of_IEEP_study_-_30_May_2014.pdf?v=63664509853.

World Bank Group. (1998). Pollution Charges: Lessons from Implementation, Pollution Prevention and Abatement Handbook, https://pdfs.semanticscholar.org/ 624d/7513083c2625dafe50d23b3a29b6ac3b8021.pdf, pp.160-168.

Yılmaz, G. \& Biyan, Ö. (2016). "Vergi Hukukunda Bir Belirsizlik: "Benzeri Mali Yükümlülük” Kavramı ve Bu Kavram Açısından Bakanlar Kuruluna Verilen Yetkilerin Değerlendirilmesi", Marmara Üniversitesi Iktisadi ve Idari Bilimler Dergisi 38 (2), pp. 349-374. 